\title{
A new record of lichenized fungus species for Antarctica: Peltigera castanea Goward, Goffinet \& Miądl.
}

\author{
Mehmet Gökhan Halıcı, Osman Muaz Osmanoğlu*, Merve Kahraman \\ Department of Biology, Faculty of Science, Erciyes University, 38039 Kayseri, Turkey
}

\begin{abstract}
As a result of our studies aiming to determine the lichen mycota of the James Ross Island (Antarctic Peninsula), we report Peltigera castanea, a species in the P. didactyla complex from Antarctica and Southern Hemisphere for the first time. Collections were evaluated using morphological, anatomical and molecular characteristics (nrITS). Peltigera castanea has foliose, 4-6 cm lobate thallus; upper surface dark brown to chestnut brown, weakly tomentose (especially in the margins of the lobes) and sorediate. The morphological and ecological variations of this species are discussed in this paper.
\end{abstract}

Key words: Antarctica, first report, lichens, biodiversity, James Ross Island

DOI: $10.5817 / \mathrm{CPR} 2020-1-5$

\section{Introduction}

Peltigera is one of the earliest generic lichen names proposed by Willdenow (1787). It is an extensively distributed genus of primarily terricolous and muscicolous macrolichens with more than 90 species recognized worldwide. Many early authors such as Acharius (1794), Duby (1830), Fries (1831) and Nylander (1863, 1866) used the name Peltigera as a synonym for Peltidea and they contributed the taxonomy of Peltigera and allied genera (Turk et al. 2015). Most of the Peltigera species are bipartite symbioses, with one cyanobacterial or chlorococoid photobiont and one mycobiont. Peltigera species have thalli that range in colour from bluish grey to dark green and brown when moist (Manoharan-Basil et al. 2016). Usually the mem- bers of Peltigera have the largest thalli among lichens and this genus occupies a central position in the family Peltigeraceae (Miadlikowska and Lutzoni 2000).

In the austral summer of 2017; the first author collected lichens from James Ross Island, which is located in the North east part of Antarctic Peninsula. One of the Peltigera specimens was studied in detail and also its nrITS gene region. As a result, we concluded that this specimen belongs to Peltigera castanea which was previously known from British Columbia (Canada), Russia and Estonia (Goffinet et al. 2003, Degtjarenko et al. 2018, Magain et al. 2018). In the literature there are seven Peltigera species previously reported from Antarctica. These species are Peltigera

Received May 11, 2020, accepted July 16, 2020.

*Corresponding author: O. M. Osmanoğlu <osmanogluosmann@gmail.com>

Acknowledgements: The first author thanks for Erciyes University for their financial support to make the field works in James Ross Island, Antarctica and TÜBITAK (118Z587) coded project. The authors are thankful for the infrastructure and facilities of J.G. Mendel station (project CzechPolar2 - LM2015078) provided during the Czech Antarctic expedition, Jan-Feb 2017. 
didactyla, Peltigera rufescens, Peltigera neckeri, Peltigera antarctica, Peltigera aubertii, Peltigera patagonica and Peltigera ponojensis (Øvstedal and Lewis-Smith 2001, 2009; Halıc1 et al. 2018). In this

\section{Material and Methods}

Lichen sample (JR 0.297; the locality of specimen is specified below) was collected from Solorina Valley, James Ross Island in Antarctica. Solorina valley is one of the longest valleys in the deglaciated area of James Ross Island and is a representative of the typical geomorphological landscape of this region. Samples of freshly collected specimens were cleaned under a stereoscopic microscope and deposited in $\mathrm{ERCH}$ Lichen Herbarium.

Morphology and anatomy of the specimens were studied using an Olympus

\section{DNA isolation, PCR and sequencing}

Lichen thalli without any fungal infection and visible damage were chosen for DNA isolation and little thallus fragments from tips of lobes were taken under a stereomicroscope. For DNA extraction, DNeasy Plant Mini Kit (Qiagen) were applied to sample according to manufacturer's instructions. PCR amplifications of ITS were performed using fungal-specific primers ITS4 (TCCTCCGCTTATTGATATGC) (White et al. 1990) and ITS1-F (CTTGGTCATT TAGAGGAAGTAA (Gardes and Bruns 1993). The $50 \mu \mathrm{L}$ PCRs contained $3 \mu \mathrm{l}$ of $10 \mathrm{x}$ reaction buffer, $3 \mu \mathrm{l} \mathrm{MgCl} 2(50 \mathrm{mM})$, $0.5 \mu \mathrm{l}$ each primer (ITS1F and ITS4), $1 \mu \mathrm{l}$ paper, we report Peltigera castanea as the eighth species of Peltigera in Antarctica, and provide detailed information about morphology, anatomy and molecular information of $P$. castanea.
SXZ 1000 stereomicroscope and a Leica DM 1000 Light microscope. For chemical constituents spot test reactions were applied under stereomicroscope. Thin layer chromotography (TLC) was carried out to determine some of the compounds in solvent system $C$ (Orange et al. 2010) when the results of spot tests were inconclusive.

JR 0.297: Antarctica, Antarctic Peninsula, James Ross Island, Solorina Valley $63^{\circ} 52^{\prime} 39.0^{\prime \prime} \mathrm{S}, 57^{\circ} 46^{\prime} 51.6^{\prime \prime} \mathrm{W}$, alt. $2 \mathrm{~m}$, on moss, leg. M. G. Halıcı \& M. Barták, 12.01.2017 (ERCH JR 0.279).
dNTP $(10 \mathrm{mM}), 0.1 \mu \mathrm{l}$ Taq DNA polymerase, $3 \mu \mathrm{l}$ of genomic DNA and $38.9 \mu \mathrm{l}$ $\mathrm{dH}_{2} \mathrm{O}$. PCR amplifications were carried out in a thermal cycler equipped with a heated lid, with the following conditions: an initial heating step for $5 \mathrm{~min}$. at $95^{\circ} \mathrm{C} ; 6$ cycles with $1: 30 \mathrm{~min}$. at $94^{\circ} \mathrm{C}, 1: 30 \mathrm{~min}$. at $55^{\circ} \mathrm{C}$, and $2 \mathrm{~min}$. at $72^{\circ} \mathrm{C}$; and 33 cycles with $1 \mathrm{~min}$. at $94^{\circ} \mathrm{C}, 1 \mathrm{~min}$. at $52^{\circ} \mathrm{C}$, and $2 \mathrm{~min}$. at $72^{\circ} \mathrm{C}$. A final extension step of $8 \mathrm{~min}$. at $72^{\circ} \mathrm{C}$ was added, after which the samples were kept at $4^{\circ} \mathrm{C}$. Amplification products were visualized on 1\% agarose gel as a band of approximately 500 or $800 \mathrm{bp}$.

\section{Sequence alignment and phylogenetic analysis}

Sequence analyzes obtained from the PCR products were performed by the BM Labosis laboratory.Sequence identities were evaluated using by blast similarity search (Standard Nucleotide BLAST) function in
GenBank $^{\circledR}$ (NIH genetic sequence database). For sequence aligment, Clustal W option of Bioedit program was used and ITS sequence results of lichen samples and samples obtained from Genbank ${ }^{\circledR}$ were 
manually adjusted in Bioedit program (Table 1).

Ambiguous regions were delimited and excluded from the alignment. Phylogenetic tree was created by using MEGA 6 (Molecular Evolutionary Genetics Analysis) program (Tamura et al. 2013). To construct the phylogenetic tree Maximum Likelihod was chosen and Tamura 3-parameter model was used. Pairwise deletion was applied to gaps in data and for a control, the reliability of the inferred tree was tested by 1000 bootstrap replications. Solorina saccata HQ650625 was used as an outgroup.

\begin{tabular}{|c|c|c|}
\hline Species & Locality & nrITS \\
\hline Peltigera castanea & Antarctica, Solorina Valley (JR 0.279) & MT632253 \\
\hline Peltigera castanea & Canada & MH758239 \\
\hline Peltigera castanea & Canada & AY266023 \\
\hline Peltigera castanea & Canada & AY266019 \\
\hline Peltigera castanea & Canada & AY266025 \\
\hline Peltigera antarctica & Chile & MH758274 \\
\hline Peltigera antarctica & Antarctica, South Orkney Islands & MH758275 \\
\hline Peltigera antarctica & Chile & MH758273 \\
\hline Peltigera canina & USA & MH758486 \\
\hline Peltigera canina & USA & MH758487 \\
\hline Peltigera didactyla & Norway & MH758244 \\
\hline Peltigera didactyla & USA & MH758245 \\
\hline Peltigera didactyla & Canada & MH758242 \\
\hline Peltigera extenuata & USA & MH758253 \\
\hline Peltigera extenuata & USA & MH758254 \\
\hline Peltigera lambinonii & Australia & AY257933 \\
\hline Peltigera lambinonii & Zaire & AY257934 \\
\hline Peltigera lambinonii & Zaire & AY266037 \\
\hline Peltigera monticola & USA & MH758313 \\
\hline Peltigera monticola & USA & MH758311 \\
\hline Peltigera neckeri & Norway & MK811778 \\
\hline Peltigera neckeri & Norway & MK811968 \\
\hline Peltigera neocanina & USA & MH758395 \\
\hline Peltigera neocanina & USA & MH758396 \\
\hline Peltigera neocanina & USA & MH758397 \\
\hline Peltigera neocanina & USA & MH758398 \\
\hline Peltigera rufescens & USA & MH758371 \\
\hline Peltigera rufescens & USA & MH758370 \\
\hline Peltigera sorediifera & Australia & MH758255 \\
\hline Peltigera sorediifera & Australia & MH758256 \\
\hline Peltigera ulcerata & Costa Rica & MH758264 \\
\hline Peltigera ulcerata & Peru & MH758265 \\
\hline Peltigera vainioi & Colombia & MH758268 \\
\hline Peltigera vainioi & Ecuador & MH758269 \\
\hline Solorina saccata & USA & HQ650625 \\
\hline
\end{tabular}

Table 1. Sequences used in the analyses; newly produced one is in bold and the others were downloaded from the Genbank ${ }^{\circledR}$. 


\section{Results and Discussion}

\section{Molecular results}

The ITS sequence of Antarctic P. castanea collected from Solorina Valley was blasted against the database of ITS sequences of 13 known Peltigera species and the related genus Solorina for an outgroup.

\section{Morphology}

Peltigera castanea was described by Goffinet et al. (2003) with a detailed description. Below we provide a description of the Antarctic specimens of this species:

Thallus is foliose, small, 4-6 cm across, lobate; lobes are usually with upturned margins, $1-1.2 \mathrm{~cm}$ wide, $3-4.5 \mathrm{~cm}$ long, mostly strongly concave and sometimes weakly overlapping. Upper surface is bluish gray in the field but after waiting in the herbarium dark brown to chestnut brown, weakly tomentose (especially in the margins of the lobes), sorediate (Fig. 2).

Soredia are mostly clustered in a rounded soralia, brown. Lower surface is white to light cream with indistinct veins; rhizines present usually near the lobe tips and brownish or concolorous with veins and flocculent (Fig. 3). All spot tests are negative (thallus and medulla $\mathrm{K}-, \mathrm{C}-, \mathrm{KC}-, \mathrm{KI}-$, $\mathrm{I}-, \mathrm{Pd}-)$. Photobiont is cyanobacterial, visible as dull blue-green layer. No apothecia or pycnidia were seen in the Antarctic specimens. TLC: No compounds were observed.

Peltigera castanea is a well-delimited species belonging to $P$. didactyla complex which comprises species of the section Peltigera with laminal or submarginal soredia (Goffinet et al. 2003). Goffinet et al. (2003) recognized 5 morphospecies in this complex by nrDNA sequences: $P$. castanea, $P$. didactyla, P. extenuata, $P$. lambinonii, and $P$. ulcerata. Unfortunately it may be very difficult to seperate these taxa in the field, and a detailed morphological and chemical works supported by molecu-
The resulting phylogenetic tree clearly shows that our Antarctic Peltigera specimen (JR 0.279) is well matched with Canadian $P$. castanea specimens (Fig. 1).

lar data is very important in the taxonomy of this complex. The most important morphological taxonomical character which seperates $P$. castanea from all these species is its characteristic chestnut brown upper surface. Moreover, $P$. ulcerata differs from $P$. castanea by having shiny upper surface which is not tomentose (even in the margins of the lobes) and more or less elongate soralia. The rhizines forms a dense mat in $P$. lambinonii whereas they are more sparse in P. castanea. P. extenuata, which is morphologically closest species to $P$. castanea, typically has gyrophoric acid derivates in the soralia (Goffinett et al. 2003).

$P$. didactyla, the only known species of the $P$. didactyla complex in Antarctica, has a cosmopolitian distribution in Antarctic Peninsula including James Ross Island (Lewis-Smith 1988, 2005a, b; Sancho et al. 1999, Egan 2006, Moudrá 2007, Zúñiga et al. 2015). This species often has apothecia in the margins of the lobes. P. castanea has rarely apothecia. Our samples of $P$. castanea which collected from James Ross Island have no apothecia. It can be hard to distinguish $P$. didactyla without apothecia from $P$. castanea but in this case rhizines should be observed more carefully as $P$. castanea has flocculent rhizines and $P$. didactyla has more discrete rhizines which are non- flocculent. In our opinion all the materials reported as $P$. didactyla from Antarctic Peninsula should be more carefully checked and also fingerprinted for a more precious classification. 


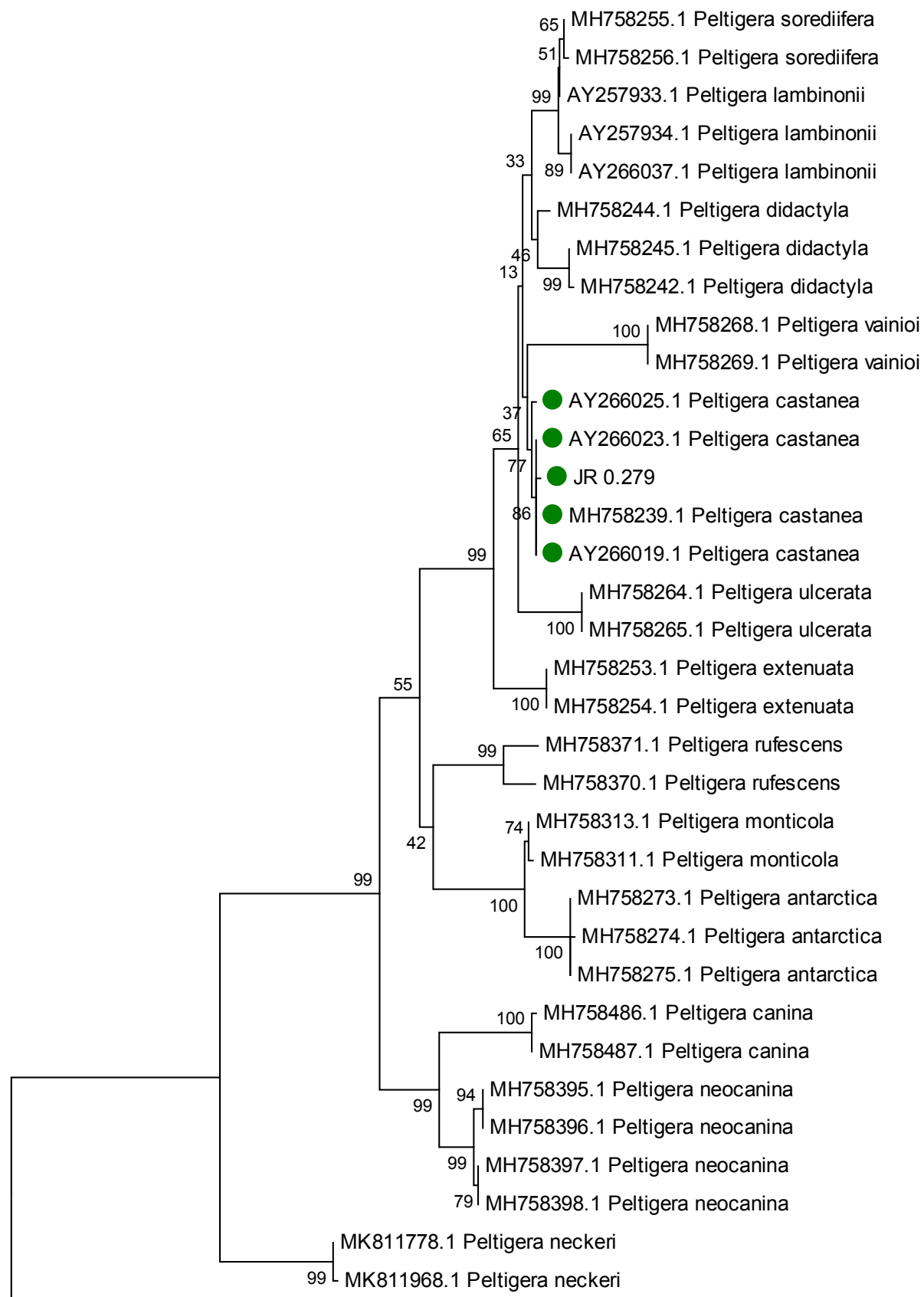

HQ650625.1 Solorina saccata

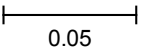

Fig. 1. Maximum Likelihood (ML) analysis inferred from ITS region sequences of Peltigera castanea and related species. 


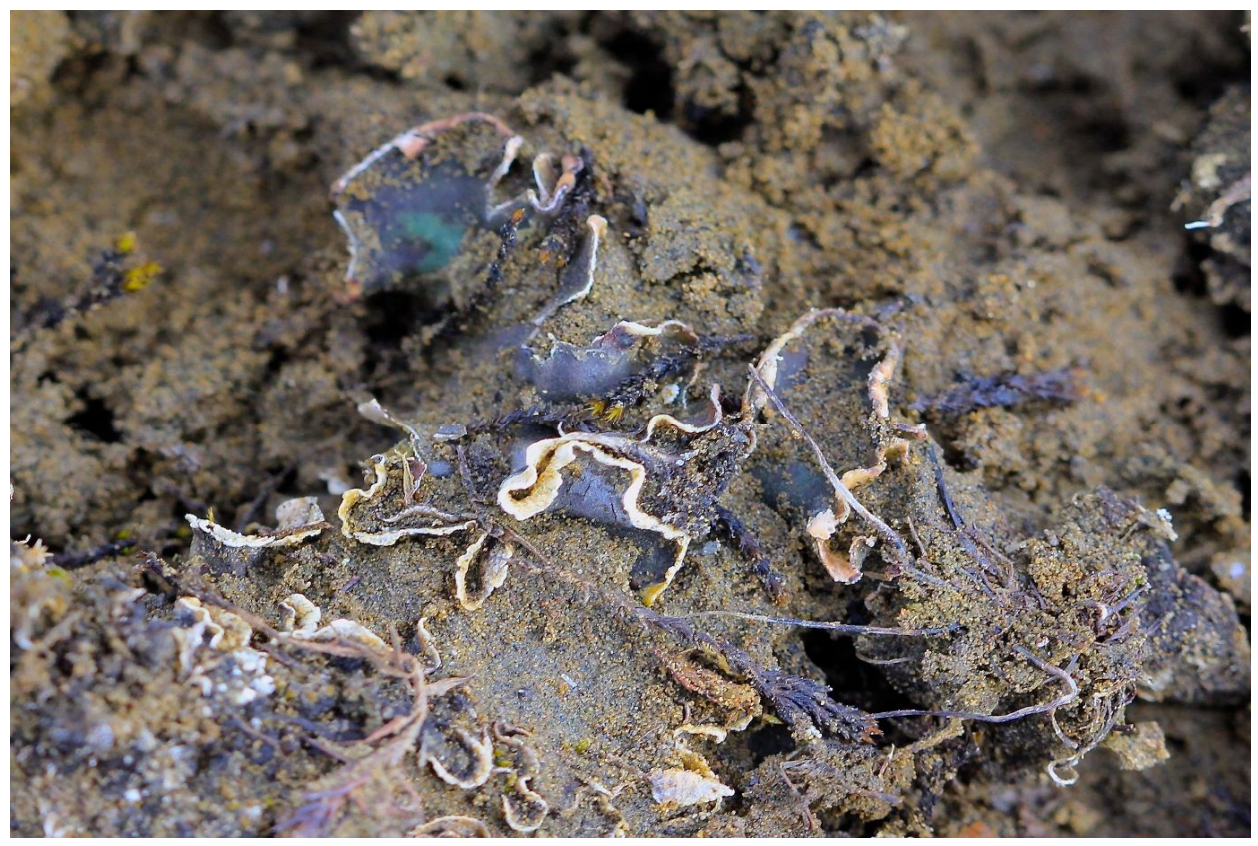

Fig. 2. Habitus of Peltigera castanea.

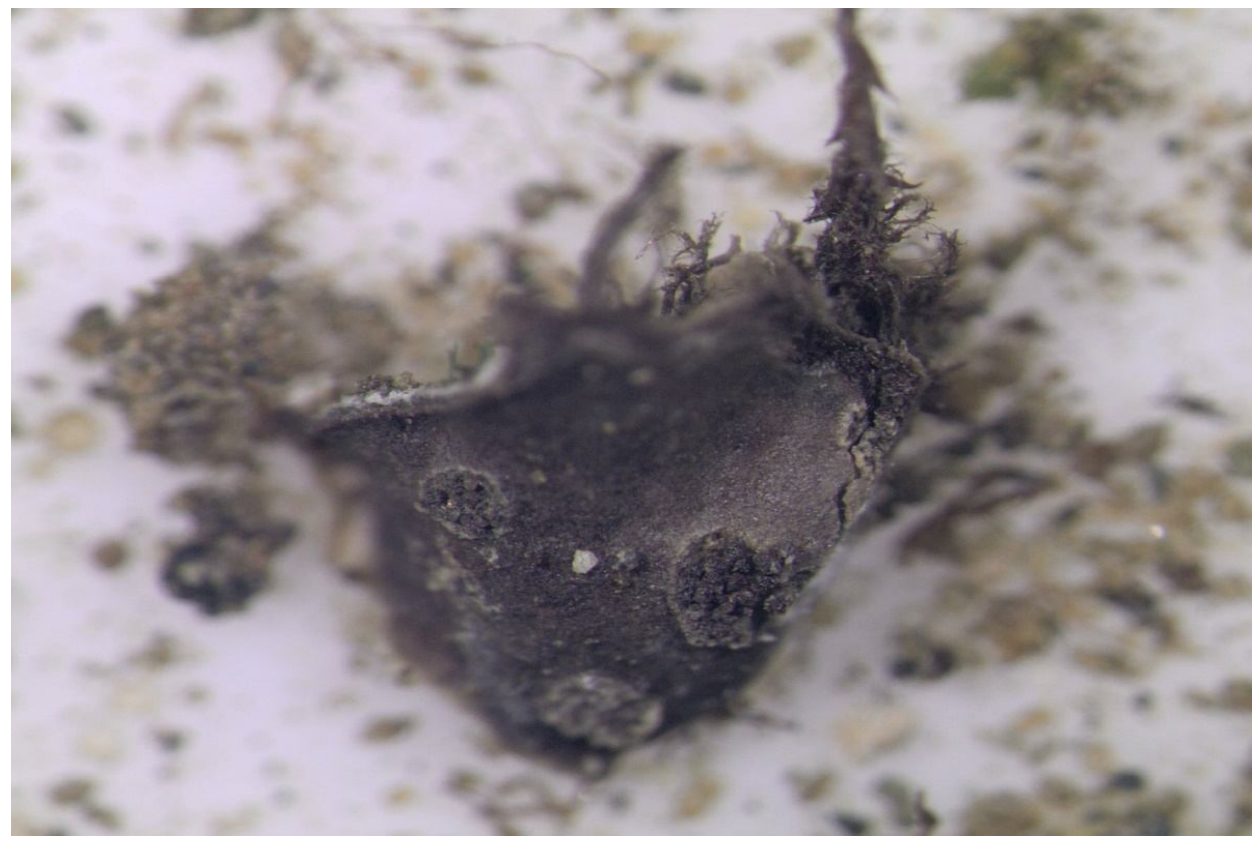

Fig. 3. Peltigera castanea from Solorina Valley, James Ross Island, Antarctica showing the rounded soralia and flocculent rhizines. 


\section{Ecology and Distribution}

P. castanea was previously reported from 2018, Magain et al. 2018). This is the first North America (Canada), Russia and Esto- record of P. castanea in Antarctica and in nia (Goffinet et al. 2003, Degtjarenko et al. Southern Hemisphere (Fig. 4).

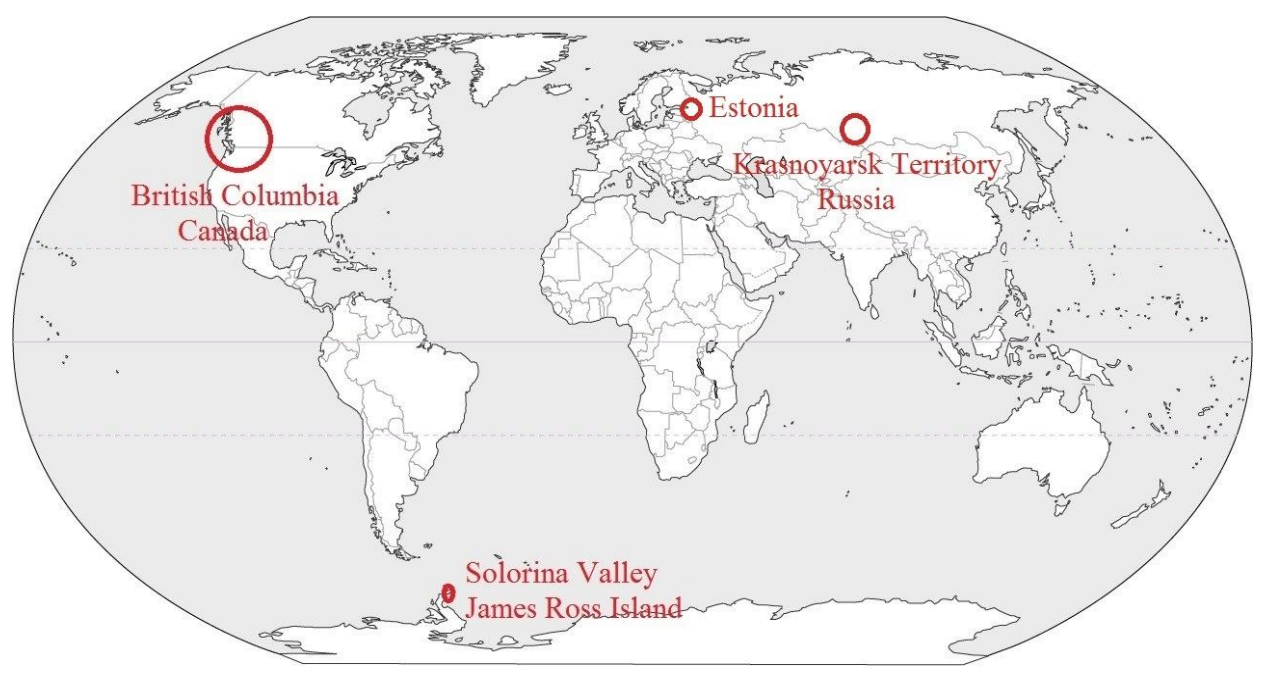

Fig. 4. Distribution map of $P$. castanea.

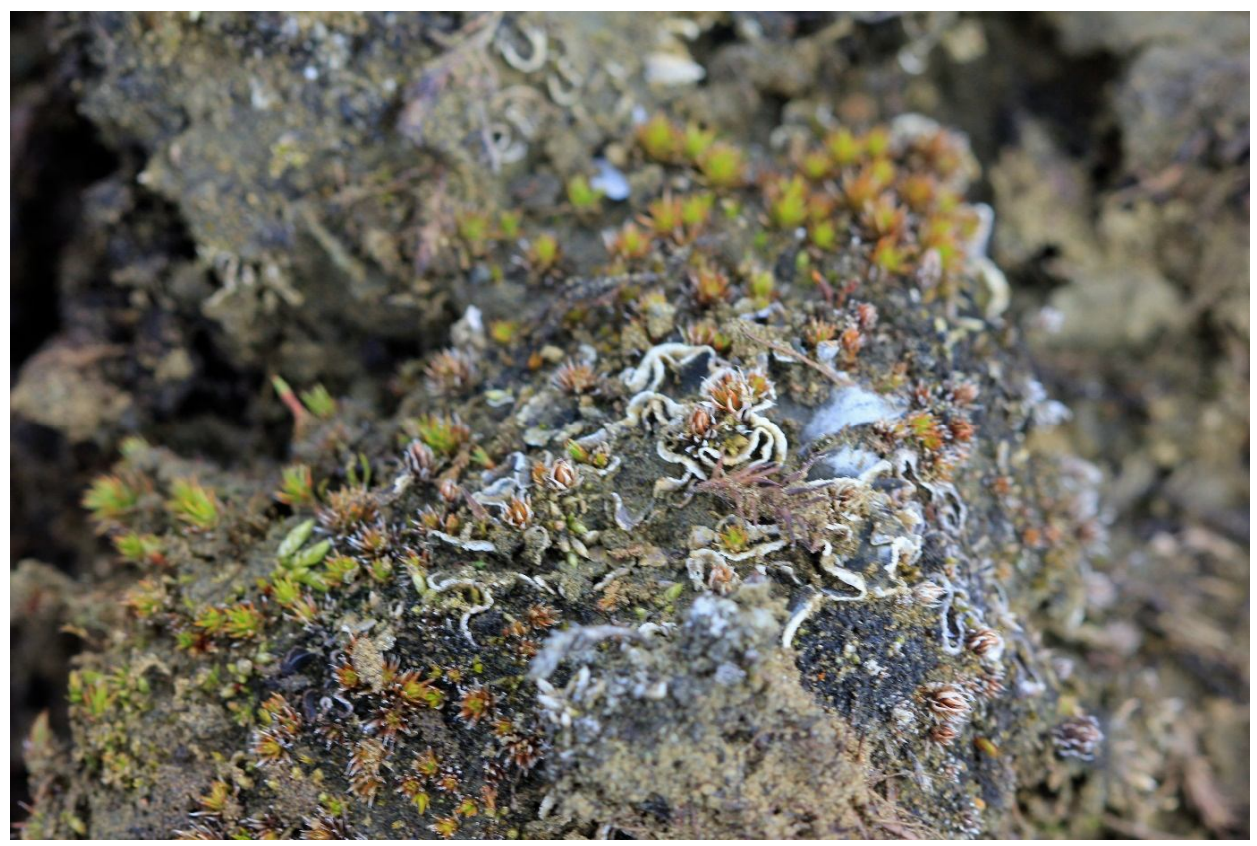

Fig. 5. P. castanea growing on moss in Solorina Valley, James Ross Island. 
According to literature (Goffinet et al. 2003, Degtjarenko et al. 2018, Magain et al. 2018), this species prefers (oro)boreal forests and alpine heaths especially in open sites on xerophytic moss mats.

The specimens which were collected from Solorina Valley (James Ross Island) grew on soil or on mosses in the sandy terrace very close to seashore. At the sampling point, the terricolous lichens of the genera Solorina, Cladonia and Psoroma grew along with $P$. castanea (Fig. 5).

The area of the Solorina Valley outlet is rich in moss flora forming irregular patches along the seashore and margins of the Solorina stream. Several shallow depressions are located over the terrase. They are filled by meltwater at the begining of austral summer season and rich in microbiological mats formed by tens of algal and cyanobacterial species (Skácelová and Barták 2014). The regolith from Solorina Valley was analyzed by Coufalík et al. (2015), who revealed low mercury levels originated from weathering of bedrock. Consequently, Zvěřina et al. (2018) studied levels of cadmium, lead, and mercury in Usnea antarctica lichens.

\section{References}

ACHARIUS, E. (1794): Försök til en förbattrad lafvarnes indelning (Dianome Lichenum). Kongl.Vetensk. Acad. Nya Handl., 15: 237-259.

Coufalík, P., Zvěřina, O., KrmíčeK, L., PoKornÝ, R. and KomÁreK, J. (2015): Ultra-trace analysis of $\mathrm{Hg}$ in alkaline lavas and regolith from James Ross Island. Antarctic Science, 27(3): 281-290.

Degtjarenko, P., Juriado, I. and Lõhmus, P. (2018): New Estonian records: Lichenized fungi. Folia Cryptogamica Estonica, 55: 151-154.

DuBY, J. E. (1830): Aug. Prami de Condolle Botanicon Gallicum. 2: 545-1068.

EgAN, R. S. (2006): Recent literature on lichens - 201. The Bryologist, 109(2): 265-275.

FRIES, T. M. (1831): Lichenographia europaea reformata. Lund: Berling, 676 p.

GARDES, M., BRUNS, T. D. (1993): ITS primers with enhanced specificity for basidiomycetes. Application for the identification of mycorrhizae and rusts. Molecular Ecology, 2: 113-118.

Goffinet, B., Miadlikowska, J. and Goward, T. (2003): Phylogenetic inferences based on nrDNA sequences support five morphospecies within the Peltigera didactyla complex (lichenized Ascomycota). Bryologist, 349-364.

Halici, M. G., BARTÁK, M. and GUllu, M. (2018): Identification of some lichenised fungi from James Ross Island (Antarctic Peninsula) using nrITS markers. New Zealand Journal of Botany, 56(3): 276-290.

Lewis-Smith, R. I. (1988): Botanical survey of Deception Island. British Antarctic Survey Bulletin, (80): $129-136$.

Lewis-Smith, R. I. (2005a): Extensive colonization of volcanic ash by an unusual form of Peltigera didactyla at Deception Island, maritime Antarctic. The Lichenologist, 37(4): 367-368.

LEWIS-SMITH, R. I. (2005b): The thermophilic bryoflora of Deception Island: Unique plant communities as a criterion for designating an Antarctic Specially Protected Area. Antarctic Science, 17(1): 17-27.

Magain, N., Tniong, C., Goward, T., Niu, D., Goffinet, B., Sérusiaux, E. and Miadlikowska, J. (2018): Species delimitation at a global scale reveals high species richness with complex biogeography and patterns of symbiont association in Peltigera section Peltigera (lichenized Ascomycota: Lecanoromycetes). Taxon, 67(5): 836-870.

Manoharan-Basil, S. S., Miadlikowska, J., Goward, T., Andresson, O. S. and Vivian, P. W. (2016): Peltigera islandica, a new cyanolichen species in section Peltigera ('P. canina group'). The Lichenologist, 48(5): 451-467. 
Miadlikowska, J., Lutzoni, F. (2000): Phylogenetic revision of the genus Peltigera (lichenforming Ascomycota) based on morphological, chemical, and large subunit nuclear ribosomal DNA data. International Journal of Plant Sciences, 161(6): 925-958.

MoudRÁ, A. (2007): Ecophysiological studies of lichens along Antarctic Peninsula. Bachelor Thesis, Masaryk University Faculty of Science, Institute of Experimental Biology, 59 p.

NyLANDER, W. (1863): Circa lichenes Armoricae et Alpium Delphinatus observationes. Acta Societatis Scientiarum Fennicae, 7: 391-413.

NYLANDER, W. (1866): De cephalodiis in Peltidea venosa. Flora, 24: 116.

Orange, A., James, P. W. and White, F. J. (2010): Microchemical methods for the identification of lichens. London: British Lichen Society, $101 \mathrm{p}$.

Øvstedal, D. O., Lewis-Smith, R. (2001): Lichens of Antarctica and South Georgia: A guide to their identification and ecology. Cambridge University Press, $424 \mathrm{p}$.

ØvSTEDAL, D. O., Lewis-SMith, R. (2009): Further additions to the lichen flora of Antarctica and South Georgia. Nowa Hedwigia, 88(1-2): 157-168.

Sancho, L. G., Schulz, F., Schroeter, B. and Kappen, L. (1999): Bryophyte and lichen flora of South Bay (Livingston Island: South Shetland Islands, Antarctica). Nova Hedwigia, 68(3): 301338.

SKÁCElovÁ, K., BARTÁK, M. (2014): Gradient of algal and cyanobacterial assemblages in a temporary lake with melting water at Solorina Valley, James Ross Island, Antarctica. Czech Polar Reports, 4(2): 185-192.

Tamura, K., Stecher, G., Peterson, D., Filipski, A. and Kumar S. (2013): MEGA6: Molecular Evolutionary Genetics Analysis version 6.0. Molecular Biology and Evolution, 30: 2725-2729.

Turk, A., Halici, M. G., Candan, M. and Yavuz, Y. (2015): The lichenized fungus genus Peltigera in Turkey. Biological Diversity and Conservation, 8(2): 146-156.

White, T. J., Bruns, T. D., Lee, S. and TAYLOR, J. (1990): Amplification and direct sequencing of fungal ribosomal DNA genes for phylogenies. In: A. Innis, D. H. Gelfand, J. J. Sninsky, T. J. White (eds.): PCR Protocols: A Guide to Methods and Applications. San Diego, CA, USA: Academic Press, pp. 315-322.

WiLLDENOW, C. L. (1787): Florae berolinnesis prodromus, Berlin, 439 p.

Zúñiga, C., Leiva, D., Ramírez-Fernández, L., Carú, M., Yahr, R. and Orlando, J. (2015): Phylogenetic diversity of Peltigera cyanolichens and their photobionts in Southern Chile and Antarctica. Microbes and environments, ME14156.

Zvěřina, O. Coufalík, P., Barták, M., Petrov, M. and Komárek, J. (2018): The contents and distributions of cadmium, mercury, and lead in Usnea antarctica lichens from Solorina Valley, James Ross Island (Antarctica). Environmental Monitoring and Assessment, 190(1): 13. 